\title{
ANALISIS RANTAI NILAI \\ DALAM MENINGKATKAN KINERJA DAN \\ KEUNGGULAN KOMPETITIF PERUSAHAAN
}

\author{
Muksin Wijaya \\ Sekolah Tinggi Manajemen Informatika dan Komputer LIKMI \\ Jl. Ir. Juanda 96 Bandung 40132 \\ muksin.wj@gmail.com
}

\begin{abstract}
ABSTRAK
Maksud dan tujuan dari jurnal ini adalah memberikan gambaran umum dan mendasar mengenai analisis rantai nilai sebagai salah satu pendekatan dan alat bantu yang dapat digunakan untuk mengukur serta meningkatkan keunggulan kompetitif perusahaan dan menghadapi tantangan-tantangan yang ada. Di dalam tulisan ini juga kita akan mengetahui aktivitas utama yang perlu dilakukan dalam menganalisis rantai nilai, serta aktivitas-aktivitas pendukung lainnya sehingga analisis rantai nilai yang dilakukan dapat memberikan hasil dan kinerja yang lebih optimal bagi perusahaan.

Ketika kita memulai melakukan pengukuran kinerja perusahaan dengan analisis rantai nilai, kita akan dapat menemukan gambaran berbagai dimensi yang dapat kita perbaiki dan kita kembangkan lebih lanjut sehingga perusahaan kita dapat tumbuh dan berkembang dengan berkelanjutan. Dengan analisis rantai nilai, perusahaan dapat semakin memperkuat kredibilitasnya dalam menghadapi persaingan bahkan dapat semakin mengasah keunggulan kompetitif perusahaan.

Analisis rantai nilai yang dilakukan perusahaan akan membantu perusahaan untuk memberikan gambar besar mengenai efektivitas kinerja perusahaan, serta tantangantantangan yang perlu dihadapi perusahaan dalam mengimplementasi strategi. Dengan perusahaan mengetahui aspek tersebut, maka perusahaan akan dapat segera mengantisipasinya bahkan segera dapat merancang strategi yang terbaik dan pas diimplementasikan pada perusahaan berdasarkan perubahan lingkungan yang terjadi.
\end{abstract}

Kata Kunci : Keunggulan, Keunggulan Kompetitif, Analisis Rantai Nilai, Analisis Biaya.

\section{LATAR BELAKANG PENELAAHAN KINERJA PERUSAHAAN}

Pengukuran kinerja perusahaan adalah suatu hal yang penting dalam proses perencanaan, pengendalian, dan kegiatan bisnis lainnya yang dilakukan oleh perusahaan. Dengan pengukuran, perusahaan dapat memilih strategi dan struktur keuangan yang tepat, menentukan langkah-langkah strategis terhadap unit-unit bisnis perusahaan yang tidak produktif, menetapkan balas jasa internal, dan kebijakan serta kegiatan-kegiatan strategis lainnya dalam perusahaan.

Pengukuran kinerja pada awalnya secara sederhana dilakukan dengan membandingkan kinerja aktual dengan kinerja yang dianggarkan atau biaya standar sesuai dengan karakteristik pertanggungjawabannya, sedangkan pengukuran kinerja yang lebih maju menggunakan aktivitas sebagai fondasinya dan bahkan sudah menggunakan alat bantu metode-metode untuk mengukur kinerja persuahaan secara empiris. Ukuran kinerja 
dirancang untuk menilai seberapa baik suatu aktivitas dilakukan dan dapat mengidentifikasi apakah telah dilakukan perbaikan yang berkesinambungan atau hanya menjadi bagian-bagian yang berdiri sendiri. Perusahaan-perusahaan selama ini lebih banyak menggunakan pengukuran kinerja yang hanya menekankan pada aspek keuangan saja, sementara dalam perkembangan saat ini sebetulnya masih terdapat aspek-aspek lainnya yang diantaranya adalah aspek peningkatan kompetensi dan komitmen personel, peningkatan produktivitas dan cost effectiveness, proses bisnis, nilai (value) yang diberikan kepada komsumen dan lainnya. Oleh karena itu dibutuhkan tolak ukur lain sebagai pelengkap pengukuran kinerja tersebut. Hal ini diperlukan karena dapat mengarahkan para manajer pada tujuan profitabilitas jangka panjang, mutu yang tinggi, pelanggan yang loyal dan kepuasan kerja yang maksimal.

Banyak hal positif yang bisa didapat perusahaan ketika melakukan pengukuran kinerja perusahaan, pengukuran kinerja perusahaan mempunyai tujuan untuk mengukur kinerja perusahaan dibandingkan dengan tujuannya, hal ini juga merupakan alat bagi manajemen. Pengukuran kinerja merupakan alat kendali yang meliputi implementasi maupun evaluasi atas kinerja pegawai dan operasi perusahaan tersebut. Dengan demikian, pengukuran kinerja bagi perusahaan harus menjadi pertimbangan untuk dilakukan, apalagi bahwa perkembangan lingkungan internal dan eksternal perusahaan saat ini sudah menuntut perusahaan untuk terus berkembang, berinovasi, dan menunjukkan kinerja secara optimal dan berkesinambungan.

Dengan pengukuran kinerja yang baik, maka perusahaan dapat melihat dan menemukan lebih dalam hal-hal serta aktivitas-aktivitas perusahaan yang akan semakin memperkuat dan mengoptimalkan capaian kinerjanya, seperti inovasi yang bisa dilakukan, budaya perusahaan dan implementasi dari praktek manajemen yang semakin baik dan meningkat. Hal lain yang perlu menjadi perhatian adalah upaya perusahaan dalam merespon serta menghadapi kompetisi sebagai dampak dari perubahan-perubahan yang terjadi di lingkungan eksternal.

Keunggulan kompetitif perusahaan juga merupakan bagian dari aspek kinerja perusahaan yang perlu menjadi perhatian dalam suatu proses yang dinamis yang berkelanjutan, dan proses ini memerlukan suatu pengelolaan yang efektif yang pada kenyataannya akan melibatkan seluruh nilai dalam semua proses bisnis yang dilakukan perusahaan dan hal tersebut menjadi satu kesatuan mata rantai (value chain) yang utuh.

\section{PEMAHAMAN ANALISIS RANTAI NILAI (VALUE CHAIN ANALYSIS)}

Analisis Rantai Nilai (Value Chain Analysis) adalah suatu kerangka kerja yang secara rasional dan sistematis dapat memberikan penjelasan dan penilaian terhadap peran dan hubungan antara orang-orang dengan organisasi. (Bolwig et al., 2010; Rushton, 2009).

Dalam pemahaman rantai nilai, termasuk didalamnya pemahaman akan alur dari material dan aktivitas penambahan nilai yang dilakukan sampai kepada hasil berupa barang atau jasa diterima oleh konsumen. Analisis rantai nilai akan melibatkan berbagai aspek lainnya diantaranya perihal budaya organisasi, perihal ekonomis serta perihal personal dari setiap orang/karyawan perusahaan. Dengan demikian analisis rantai nilai memang cukup bersifat kompleks, dan perlu dilakukan secara bertahap, yaitu :

- Tahap pertama yaitu dengan memetakan setiap proses dalam perusahaan menjadi bagian-bagian aktivitas yang lebih spesifik

- Tahap kedua yaitu dengan menelaah lebih lanjut dari bagian-bagian aktivitas yang lebih spesifik tersebut yang berkaitan dengan biaya yang terjadi, bisa dalam bentuk waktu yang diperlukan maupun uang yang perlu dikeluarkan. 
- Tahap ketiga yaitu merubah biaya yang didapat pada tahap kedua tersebut diatas ke dalam informasi-informasi yang berkaitan dengan keunggulan maupun kelemahan kompetitif perusahaan.

Analisis rantai nilai dilakukan secara kolaboratif dari setiap dimensi proses bisnis, dan setiap dimensi itu saling berkaitan satu dengan lainnya, termasuk dimensi lingkungan internal maupun eksternal perusahaan. Analisis rantai nilai merujuk pada suatu proses untuk menemukan biaya-biaya yang diperlukan berkaitan dengan kegiatan-kegiatan perusahaan, diantaranya pembelian bahan baku, produksi, pemasaran dan kegiatan lainnya. Analisis rantai nilai bertujuan untuk mengidentifikasi efisiensi dari setiap biaya tersebut dalam suatu rangkaian nilai.

Michael E. Porter (2008) mengembangkan suatu pendekatan/alat bantu untuk melakukan analisis rantai nilai. Pendekatan ini dapat digunakan untuk melihat perusahaan secara sistematis, mulai dari proses awal sampai barang/jasa diterima konsumen. Pendekatan analisis rantai nilai yang dimaksudkan dapat kita gambarkan sebagai berikut :

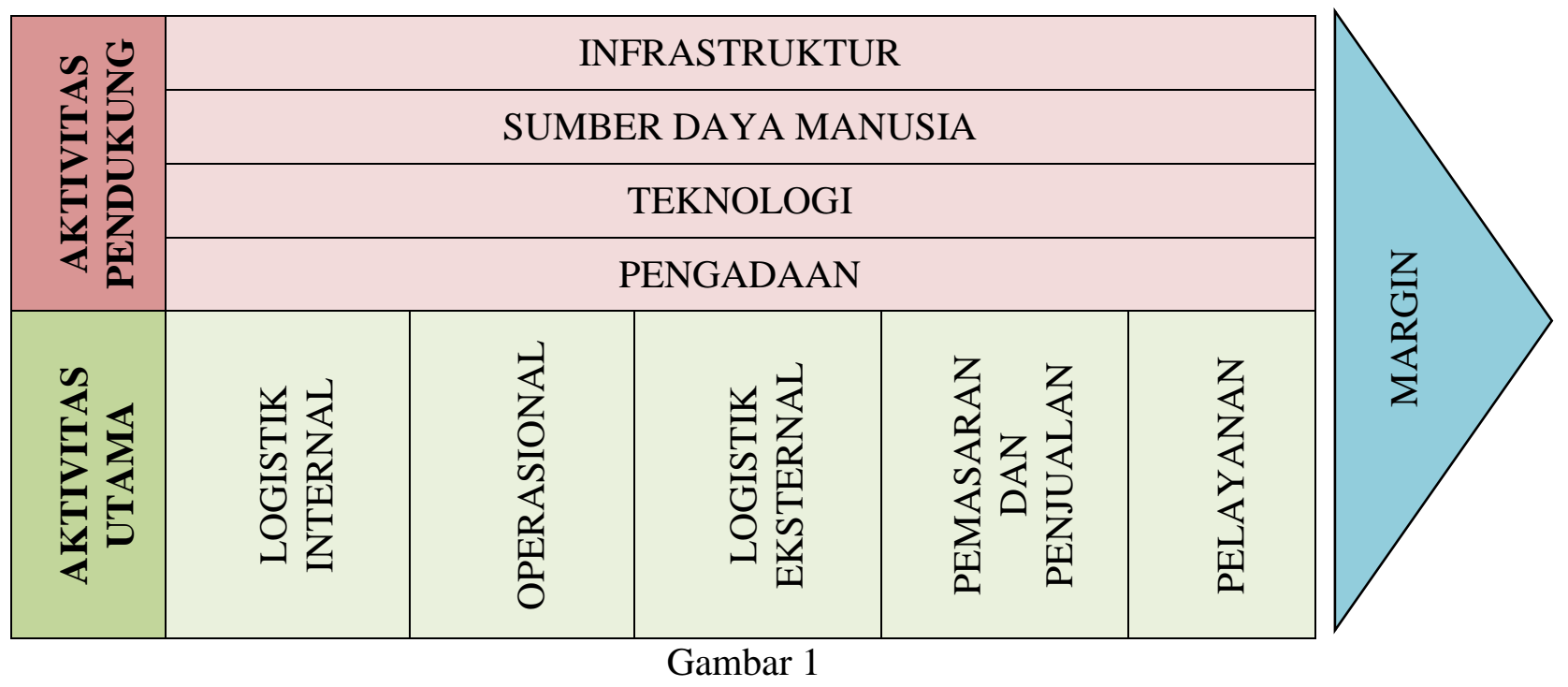

Model Rantai Nilai Porter

Berdasarkan pada gambar rantai nilai Porter diatas, kategori mendasar dari rantai nilai dikelompokan menjadi dua kelompok, yaitu kelompok aktivitas utama dan kelompok aktivitas pendukung. Aktivitas utama tercakup di dalamnya adalah kegiatan produk/jasa yang dihasilkan perusahaan, perihal pemasarannya, sampai kepada layanan purna jual atas barang dan jasa yang dijual oleh perusahaan. Aktivitas utama terdiri dari lima kategori, yaitu logistik internal perusahaan, operasional, logistis ekternal perusahaan, pemasaranpenjualan dan layanan yang diberikan kepada konsumen. Sedangkan aktivitas pendukung terdiri dari infrastruktur dari masukan yang membuat kegiatan utama dapat berlangsung secara berkelanjutan. Aktivitas pendukung terdiri dari empat kategori, yaitu pembelian, infrastruktur, sumber daya manusia, teknologi yang digunakan serta dikembangkan.

Analisis rantai nilai memberikan kemudahan kepada perusahaan untuk dapat mendeskripsikan orang-orang yang diperlukan serta dapat dapat menunjukkan kekuatan perusahaan dan kesenjangannya, sehingga perusahaan dapat menyusun skala prioritas keterlibatan serta penempatan sumberdaya yang ada ke dalam aktivitas yang ada pada rantai nilai. Analisis rantai nilai dapat membuat perusahaan semakin memahami kebiasaan dari orang-orang yang ada di dalam perusahaan, sehingga akan mempermudah bagi 
perusahaan untuk mengambil keputusan di dalam melakukan penerapan suatu perubahan dengan mengetahui dan sudah diperhitungkan kemungkinan resiko yang akan dihadapi.

Analisis rantai nilai sebagai alat bantu bagi perusahaan untuk melakukan pemeriksaan terhadap rantai nilai yang sekarang ada dan mengidentifikasi rantai nilai yang lebih baik untuk masa depan. Selain itu analisis rantai nilai dapat diterapkan dalam pemahaman meminimalkan pemborosan serta efisiensi alur bahan baku, terutama bilamana alur itu berkaitan dengan lintas organisasional. Analisis rantai nilai dapat membantu perusahaan untuk mengidentifikasi dimensi bisnis perusahaan yang lebih besar dan luas, sehingga sangat menunjang bagi perusahaan untuk bisa semakin bertumbuh dan berkembang, yang biasanya akan dinyatakan selanjutnya dalam strategi pengembangan perusahaan. (Fearne, Garcia Martinez, 2012). Analisis rantai nilai dapat pula membantu perusahaan untuk mendefinisikan dan mengupayakan perusahaan untuk mencapai keunggulan kompetitifnya.

\section{KETERKAITAN ANTAR AKTIVITAS DI DALAM RANTAI NILAI}

Setiap aktivitas perusahaan dalam sudut pandang rantai nilai pada dasarnya memiliki keterkaitan satu dengan lainnya bahkan akan membentuk suatu sistem yang saling berhubungan. Keterkaitan ini juga pada dasarnya akan terjadi pada kegiatan utama dan kegiatan pendukung sesuai model rantai nilai yang dikemukakan oleh Porter pada bagan di atas. Setiap aktivitas akan berkaitan antara satu aktivitas dengan biaya yang ditimbulkannya untuk aktivitas lainnya atau aktivitas selanjutnya.

Keterkaitan ini dapat menuntun perusahaan untuk dapat mengembangkan keunggulan perusahaan dalam dua cara, pertama dengan optimalisasi biaya dan kedua dengan koordinasi untuk mengefektifkan aktivitas yang ada tersebut. Optimalisasi biaya dalam arti perusahaan berupaya untuk menekan biaya yang timbul, terutama untuk aktivitas perusahaan yang cenderung menimbulkan biaya tinggi. Koordinasi efektifitas aktivitas dalam arti perusahaan berupaya untuk semakin memperkuat diferensiasinya, misalnya dengan menjadwalkan aktivitas produksi dengan aktivitas pengantaran barang yang memungkinkan perusahaan untuk menekan biaya penyimpanan di gudang. Keterikatan antar aktivitas perusahaan yang paling mendasar menurut Porter (1985) termasuk di dalamnya adalah dalam melakukan fungsi yang sama dengan cara yang berbeda-beda, dan sebagainya.

\section{KEUNGGULAN KOMPETITIF}

Menurut Hill and Jones (2002), keungulan kompetitif adalah kemampuan perusahaan untuk menghadapi kompetitornya dalam satu industri yang sama. Keunggulan kompetitif merupakan keunggulan perusahaan dalam memberikan nilai lebih dibandingkan dengan kompetitornya, misalnya perusahaan dapat memberikan nilai berupa harga yang relatif lebih murah, memberikan nilai benefit dan layanan dibandingkan dengan kompetitornya. Menurut Grant (1998), keunggulan kompetitif adalah kemampuan perusahaan untuk dapat mencapai terus tingkat keuntungan yang optimal dibandingkan dengan kompetitornya.

Kerapkali ketika perusahaan merujuk kepada keunggulan kompetitif, biasanya yang dimaksudkan adalah kekuatan hakiki yang dimiliki perusahaan kita terhadap kompetitor kita. Menurut Jones (2001) kekuatan perusahaan pada hakekatnya bisa dicapai dengan suatu inovasi dan penataan kembali struktur perusahaan. Porter (1980) mengidentifikasikan strategi mendasar yang dapat diadopsikan perusahaan dalam konteks keunggulan kompetitif, yaitu strategi diferensiasi, strategi biaya. 


\section{RANTAI NILAI DAN ANALISIS BIAYA}

Keunggulan biaya sebagaimana dituliskan diatas adalah salah satu dari bentuk keunggulan kompetitif yang dapat diupayakan perusahaan. Biaya berperan penting dalam strategi diferensiasi karena diferensiator perlu mempertahankan biayanya, jangan sampai melebihi kompetitor. Porter (1985) telah mengamati bahwa perusahaan yang mengembangkan keunggulan kompetitifnya dari segi biaya, pada awalnya perusahaan tersebut telah melakukan analisis aktivitas rantai nilainya. Menurut Porter terdapat sepuluh aspek pemicu biaya yang berkaitan dengan suatu rantai nilai, yaitu skala ekonomi, pembelajaran, kapasitas pemanfaatan, keterkaitan antar aktivitas, hubungan antar unit bisnis, derajat integrasi vertikal, waktu memasuki pasar, kebijakan perusahaan dalam hal biaya, lokasi geografis, faktor institusional (regulasi, pajak).

Faktor skala ekonomi muncul dari kemampuan perusahaan dalam melakukan aktivitas usahanya dengan cara yang berbeda dan lebih efisien untuk volume yang besar atau kemampauan perusahaan untuk menekan biaya-biaya intangible. Biaya yang timbul atas suatu aktivitas usaha dalam rantai nilai dapat diturunkan sebanding dengan peningkatan efisiensi yang akan didapatkan perusahaan.

Terdapat dua tipe keterkaitan antar aktivitas, yaitu keterkaitan diantara rantai nilai dan keterkaitan dengan rantai nilai para pemasok dan jalur distribusi, hal ini menjelaskan kepada kita bahwa dalam mempelajari biaya atas nilai aktivitas yang saling berkaitan ini, perusahaan tidak dapat melakukan analisis aktivitas secara berdiri sendiri, namun harus dianalisis secara bersama-sama antar aktivitas yang saling berkaitan tersebut.

Integrasi dapat menurunkan biaya dalam berbagai cara, misalnya dengan melakukan penggabungan operasional dapat menurutkan biaya yang awalnya muncul ketika suatu operasional dilakukan secara masing-masing.

Porter (2004) mengamati bahwa terdapat dua cara yang dapat dilakukan perusahaan untuk mencapai keunggulan biayanya, yaitu: mengendalikan aspek pemicu timbulnya biaya tersebut dan melakukan konfigurasi kembali dari rantai nilainya dengan mengadopsikan cara yang berbeda dan yang lebih efisien. Setiap perusahaan diharapkan dapat secara agresif menekan biaya yang timbul atas aktivitas-aktivitas yang tidak berpenngaruh signifikan terhadap diferensiasi.

\section{DIFERENSIASI DAN RANTAI NILAI}

Menurut Grant (1998), perusahaan dapat meraih keunggulan diferensiasi dari berbagai hal yang ada pada suatu rantai nilai, misalnya dalam pengadaan inputan proses bisnis yang sangat unik yang tidak dimiliki kompetitornya, sehingga pada saat didistribusikan, perusahaan dapat menawarkan tingkat layanan yang optimal. Diferensiasi berasal dari uniksitas, bisa diperoleh dengan cara merubah aktivitas rantai nilainya pada suatu produk akhir atau dengan cara melakukan konfigurasi ulang rantai nilainya.

Menurut Porter (2004), terdapat beberapa aspek yang dapat memicu munculnya uniksitas tersebut, yaitu: kebijakan dan keputusan, keterkaitan antar aktivitas, waktu proses, lokasi, hubungan antar aktivitas, integrasi dan skala, sebagai contoh keunikan dalam memberikan layanan yang lebih baik pada skala yang lebih luas, dan sebagainya.

Kebijakan perusahaan berkenaan dengan kegiatan apa yang perlu dilakukan dan bagaimana melakukannya turut menjadi bagian penting di dalam memunculkan uniksitas. Misalnya kebijakan perusahan berkaitan dengan yang fitur suatu produk dan jasa yang ditawarkan, tampilan produk dan jasa yang ditawarkan, ketrampilan karyawan yang diperlukan untuk produksi barang dan jasa tersebut dapat menjadi bagian yang akan memunculkan suatu uniksitas. 
Uniksitas seringkali pula berasal dari upaya perusahaan di dalam pemenuhan kebutuhan para konsumen, dalm hal ini biasanya melibatkan koordinasi dengan para pemasok dan jalur jalur distribusi. Koordinasi yang baik dengan para pemasok dan menciptakan model yang lebih singkat dalam distribusi juga dapat menjadi peluang memunculkan uniksitas.

Uniksitas suatu aktivitas perusahaan dapat pula berawal dari suatu pembelajaran yang dilakukan perusahaan tentang bagaimana perusahaan dapat melakukan suatu aktivitas dengan lebih baik tanpa mengorbankan kualitas bahkan semakin meningkatkan nilai.

Porter (2004) memberikan catatan bahwa skala usaha yang lebih besar dapat memberikan dampak bagi suatu aktivitas dapat dilakukan dengan cara lain yang unik dibadingkan apabila dilakukan dalam skala yang lebih kecil.

Selain itu, Kottler \& Keller (2006) memberikan catatan pula bahwa meningkatnya performa konsumen, akan sangat bergantung pada pemahaman akan performa seperti apa yang diharapkan para konsumen terhadap perusahaan. Konsumen akan cenderung menilai value yang diberikan oleh perusahaan berdasarkan antara lain beberapa faktor iklan yang ditayangkan, reputasi, kemasan produk, profesionalisme, tampilan, atraktivitas dari fasilitas, dan informasi yang disediakan oleh sales presentative, dan lainnya.

Perusahaan dapat semakin memperkuat diferensiasinya dalam dua cara, yaitu menjadi semakin unik dalam menampilkan nilai yang sudah ada atau dengan menata kembali rantai nilainya. Untuk menjadi lebih unik, maka perusahaan perlu memanipulasi aspek-aspek pemicu uniksitas sebagaimana dijelaskan diatas, secara bersamaan pula, perusahaan perlu secara simultan mengendalikan biaya.

\section{KESIMPULAN}

Pengukuran kinerja perusahaan adalah suatu hal yang penting dalam proses perencanaan, pengendalian, dan kegiatan bisnis lainnya yang dilakukan oleh perusahaan.

Analisis Rantai Nilai dapat membantu perusahaan untuk dapat melakukan kegiatan usahanya dengan lebih efektif dan efisien untuk meraih keunggulannya. Keungulan kompetitif adalah kemampuan perusahaan untuk menghadapi kompetitornya dalam satu industri yang sama. Keunggulan kompetitif merupakan keunggulan perusahaan dalam memberikan nilai lebih dibandingkan dengan kompetitornya, misalnya perusahaan dapat memberikan nilai berupa harga yang relatif lebih murah, memberikan nilai benefit dan layanan dibandingkan dengan kompetitornya.

Perusahaan dapat semakin memperkuat diferensiasinya sebagai suatu keunggulan dengan cara menjadi semakin unik dalam menampilkan nilai (value) yang sudah ada atau dengan menata kembali rantai nilainya . Untuk itu perusahaan perlu memanipulasi aspekaspek pemicu keungulan dan secara bersamaan perusahaan secara simultan mengendalikan biaya.

\section{DAFTAR PUSTAKA}

Bolwig, S., Ponte, S., (2010). Integrating poverty and environmental concern into valuechain analysis: a conceptual framework.

Grant, R.M. (1998). Contemporary Strategy Analysis. $3^{\text {rd }}$ Edition, Massachusetts Blackwell Publisher Inc.

Kotler P \& Keller K.L. (2006), Marketing Management. $12^{\text {th }}$ Edition, Upper Saddle River, New Jersey, Pearson Education Inc.

Jones, D. and Womack, J. (2002), Seeing the Whole - Mapping the Extended Value Stream, Lean Entreprise Institute, Cambridge, MA. 
Porter, M.E., (1985)., Competitive Strategy. Macmillan Publishing Co., Inc., USA.

Porter, M.E., (2008). Competitive Advantage: creating and sustaining performance. Amazon Digital Services Incorporated. 